\title{
Penggunaan Bahan Ajar Matakuliah Pembelajaran Saintifik Berdasarkan Pembelajaran Matematika Untuk Meningkatkan Kemandirian Belajar Mahasiswa Calon Guru
}

\author{
Eliska Juliangkary ${ }^{1}$, Sri Yuliyanti ${ }^{2}$ dan Syahrir ${ }^{3}$ \\ 1,2\&3 Dosen prodi Pendidikan Matematika FPMIPA IKIP Mataram \\ E-mail: ${ }^{1}$ eliska01juliangkary@gmail.com, ${ }^{2}$ yuliyantisrie@gmail.com, \\ syahrir.mandala@yahoo.com
}

\begin{abstract}
Abstrak: Pendekatan saintifik menjadikan pembelajaran lebih aktif dan tidak membosankan, siswa dapat mengkonstruksi pengetahuan dan keterampilannya melalui fakta-fakta yang ditemukan dalam penyelidikan di lapangan guna pembelajaran. Bahan ajar merupakan salah satu faktor penting dalam keefektifan sebuah pembelajaran terlebih ditingkat Perguruan Tinggi. Kurangnya bahan ajar tentunya dapat mempengaruhi kualitas pembelajaran atau perkuliahan. Bahan ajar digunakan untuk melatih kemandirian. Kemandirian belajar adalah kondisi aktifitas belajar yang mandiri tidak tergantung pada orang lain, memiliki kemauan serta bertanggung jawab sendiri dalam menyelesaikan masalah belajarnya. Penelitian ini merupakan penelitian pengembangan untuk memperoleh Bahan ajar matakuliah pembelajaran saintifik berdasarkan pembelajaran matematika . Tulisan ini hanya membahas tahap uji keefektifan produk khususnya berkaitan dengan kemandirian belajar Mahasiswa calon guru. Pendekatan penelitian yang digunakan adalah penelitian deskriptif kuantitatif. Subjek penelitian ini sebanyak 34 orang mahasiswa yang terdiri dari 21 orang perempuan dan 13 orang lakilaki mengikuti matakuliah Pembelajaran Saintifik pada semester empat Program Studi Pendidikan Matematika, Pengumpulan data dalam penelitian ini yaitu dengan angket kuesioner sebanyak 36 butir pernyataan dengan menggunakan skala likert. Indikator kemandirian yang digunakan dalam penelitian ini adalah 1) Ketidaktergantungan terhadap orang lain sebesar $80 \%$ berkategori sangat positif, 2) Memiliki kepercayaan diri, sebesar 76,7\% berkategori sangat positif 3) Berperilaku disiplin, sebesar 83,3\% berkategori sangat positif 4) Memiliki rasa tanggung jawab, sebesar 73,3\% berkategori positif 5) Berperilaku berdasarkan inisiatif sendiri, sebesar 76,7\% berkategori sangat positif dan 6) Melakukan kontrol diri, sebesar $70 \%$ berkategori sangat positif. Serta hasil penelitian diperoleh total keseluruhan jawaban responden mengenai kemandirian belajar mahasiswa saat penggunaan bahan ajar matakuliah pembelajaran saintifik berdasarkan pembelajaran matematika adalah sebesar 76,7 \% yang merupakan kategori sangatpositif.
\end{abstract}

Kata Kunci: Bahan ajar, Saintifik, kemandirian belajar .

\section{PENDAHULUAN}

Pendekatan saintifik menjadikan pembelajaran lebih aktif dan tidak membosankan, siswa dapat mengkonstruksi pengetahuan dan keterampilannya melalui fakta-fakta yang ditemukan dalam penyelidikan di lapangan guna pembelajaran. Selain itu, dengan pembelajaran berbasis pendekatan saintifik ini, siswa didorong lebih mampu dalam mengobservasi, bertanya, bernalar, dan mengomunikasikan atau mempresentasikan hal-hal yang dipelajari dari fenomena alam ataupun pengalaman langsung (Kemendikbud, 2013: 203,212).
Dick, Carey, dan Carey (2009: 230) menambahkan bahwa "instructional material contain the conten either written, mediated, or facilitated by an instructor that a student as use to achieve the objective also include information thet the learners will use to guide the progress". Berdasarkan ungkapan Dick, Carey, dan Carey dapat diketahui bahwa bahan ajar berisi konten yang perlu dipelajari oleh siswa baik berbentuk cetak atau yang difasilitasi oleh pengajar untuk mencapai tujuan tertentu.Dan menurut Mulyasa (2006: 96) mengemukakan bahwa bahan ajar 
merupakan salah satu bagian dari sumber ajar yang dapat diartikan sesuatu yang mengandung pesan pembelajaran, baik yang bersifat khusus maupun yang bersifat umum yang dapat dimanfaatkan untuk kepentingan pembelajaran.

Menurut Stephen Brookfield (2000:130133) mengemukakan bahwa kemandirian belajar merupakan kesadaran diri, digerakkan oleh diri sendiri, kemampuan belajar untuk mencapai tujuannya.Desi Susilawati, (2009:78) mendiskripsikan kemandirian belajar sebagai berikut: 1. Siswa berusaha untuk meningkatkan tanggung jawab dalam mengambil berbagai keputusan. 2. Kemandirian dipandang sebagai suatu sifat yang sudah ada pada setiap orang dan situasi pembelajaran. 3. Kemandirian bukan berarti memisahkan diri dari orang lain. 4. Pembelajaran mandiri dapat mentransfer hasil belajarnya yang berupa pengetahuan dan keterampilan dalam berbagai situasi. 5. Siswa yang belajar mandiri dapat melibatkan berbagai sumber daya dan aktivitas seperti membaca sendiri, belajar kelompok, latihan dan kegiatan korespondensi. 6. Peran efektif guru dalam belajar mandiri masih dimungkinkan seperti berdialog dengan siswa, mencari sumber, mengevaluasi hasil dan mengembangkan berfikir kritis. 7. Beberapa institusi pendidikan menemukan cara untuk mengembangkan belajar mandiri melalui program pembelajaran terbuka.

Kemandirian belajar adalah kondisi aktifitas belajar yang mandiri tidak tergantung pada orang lain, memiliki kemauan serta bertanggung jawab sendiri dalam menyelesaikan masalah belajarnya. Kemandirian belajar akan terwujud apabila mahasiswa aktif mengontrol sendiri segala sesuatu yang dikerjakan, mengevaluasi dan selanjutnya merencanakan sesuatu yang lebih dalam pembelajaran yang dilalui dan mahasiswa juga mau aktif dalam proses pembelajaran.

Matakuliah Pembelajaran Saintifik bertujuan agar mahasiswa memahami konsep dasar pembelajaran saintifik dan aplikasinya dalam pengembangan pembelajaran di sekolah. Sedangkan secara khusus matakuliah ini mengkaji tentang: (1) hakikat pembelajaran saintifik, (2) keterampilan proses dalam pembelajaran saintifik yang terdiri atas keterampila mengamati, menanyakan, mengumpulkan informasi, mengasosiasi atau mengolah informasi, mengkomunikasikan, dan mencipta, (3) model-model pembelajaran yang dapat mendukung atau memperkuat pembelajaran saintifik, (4) peran pembelajaran saintifik dalam pembelajaran MIPA di sekolah. Agar perkuliahan Pembelajaran Saintifik dapat terlaksana secara efektif dan mencapai tujuannya maka diperlukan sarana pendukung berupa bahan ajar yang berkualitas dan dapat memudahkan mahasiswa dalam belajar Pembelajaran Saintifik pada Prodi Pendidikan Matematika, FSTT UNDIKMA Mataram. Oleh karena itu, peneliti akan mengkaji tentang penggunaan bahan ajar matakuliah pembelajaran saintifik berdasarkan pembelajaran matematika untuk meningkatkan kemandirian belajar Mahasiswa calon guru.

\section{METODE}

Penelitian ini merupakan penelitian pengembangan untuk memperoleh Bahan ajar matakuliah pembelajaran saintifik berdasarkan pembelajaran matematika . Tulisan ini hanya membahas tahap uji keefektifan produk khususnya berkaitan dengan kemandirian belajar Mahasiswa calon guru. Pendekatan penelitian yang digunakan adalah penelitian deskriptif kuantitatif. Subjek penelitian ini sebanyak 34 orang mahasiswa yang terdiri dari 21 orang perempuan dan 13 orang laki-laki mengikuti matakuliah Pembelajaran Saintifik pada semester empat Program Studi Pendidikan Matematika, FSTT UNDIKMA Mataram. Pengumpulan data dalam penelitian ini yaitu dengan angket kuesioner sebanyak 36 butir pernyataan dengan menggunakan skala likert sebagai alternatif pilihan yang berkaitan dengan penggunaan bahan ajar matakuliah pembelajaran saintifik berdasarkan pembelajaran matematika. Setelah itu menghitung persentase jawaban dari tiap indikator.Indikator kemandirian yang digunakan dalam penelitian ini adalah 1) Ketidaktergantungan terhadap orang lain, 2) Memiliki kepercayaan diri, 3) Berperilaku 
disiplin, 4) Memiliki rasa tanggung jawab, 5) Berperilaku berdasarkan inisiatif sendiri, dan 6) Melakukan kontrol diri (Hidayati, 2007) Setelah diperoleh hasil persentase tiap indikator, kemudian peneliti menarik kesimpulan terhadap hasil penelitian. peneliti menggunakan pedoman dari Sugiyono (2011) yaitu "semakin tinggi persentase responden maka semakin baik pula persepsi responden". Ketentuan skala persentase yang digunakan untuk menyimpulkan data hasil penelitian dapat dilihat pada tabel sebagai berikut:

\section{Tabel 1 Kriteria Interpretasi Skor}

\begin{tabular}{|l|l|l|}
\hline No & Rentang Skor & Kategori \\
\hline 1 & $76-100$ & Sangat Positif \\
\hline 2 & $51-75$ & Positif \\
\hline 3 & $26-50$ & Negatif \\
\hline 4 & $1-25$ & Sangat Negatif \\
\hline
\end{tabular}

\section{HASIL DAN PEMBAHASAN}

Analisis data penggunaan bahan ajar matakuliah pembelajaran saintifik berdasarkan pembelajaran matematika untuk meningkatkan kemandirian belajar Mahasiswa calon guru berdasarkan pada enam indikator kemandirian belajar yaitu : 1) Ketidaktergantungan terhadap orang lain, 2) Memiliki kepercayaan diri, 3) Berperilaku disiplin, 4) Memiliki rasa tanggung jawab, 5) Berperilaku berdasarkan inisiatif sendiri, dan 6) Melakukan kontrol diri. Data skor dari perhitungan indikator adalah sebagai

berikut :

Tabel 2. Analisis kemandirian belajar mahasiswa

\begin{tabular}{|l|l|l|l|}
\hline No & \multicolumn{1}{|c|}{ Indikator } & Persentase & \multicolumn{1}{c|}{ Kategori } \\
\hline 1. & Ketidaktergantungan terhadap orang lain & $80 \%$ & Sangat positif \\
\hline 2. & Memiliki kepercayaan diri & $76,7 \%$ & Sangat positif \\
\hline 3. & Berperilaku disiplin & $83,3 \%$ & Sangat positif \\
\hline 4. & Memiliki rasa tanggung jawab & $73,3 \%$ & Positif \\
\hline 5. & Berperilaku berdasarkan inisiatif sendiri & $76,7 \%$ & Sangat positif \\
\hline 6. & Melakukan kontrol diri & $70 \%$ & Positif \\
\hline & Total & $76,7 \%$ & Sangat positif \\
\hline
\end{tabular}

Subjek penelitian ini sebanyak 34 orang mahasiswa yang terdiri dari 21 orang perempuan dan 13 orang laki-laki mengikuti matakuliah Pembelajaran Saintifik pada semester empat Program Studi Pendidikan Matematika, FSTT UNDIKMA Mataram. Dari hasil penelitian diperoleh total keseluruhan jawaban responden mengenai kemandirian belajar mahasiswa saat penggunaan bahan ajar matakuliah pembelajaran saintifik berdasarkan pembelajaran matematika adalah sebesar 76,7 $\%$ yang merupakan kategori sangat positif. Hal tersebut dapat dilihat dari rincian setiap indikator sebagai berikut:

Berdasarkan table. 2 terlihat bahwa indikator pertama: Ketidaktergantungan terhadap orang lain sebesar $80 \%$ yaitu berada pada kategori sangat positif. Hal ini menunjukkan bahwa mahasiswa belajar dengan menggunakan bahan ajar matakuliah pembelajaran saintifik berdasarkan pembelajaran matematika tidak bergantung pada orang lain. Mereka berusaha untuk belajar secara mandiri untuk memperoleh tujuan yang ingin dicapai. Dan sesuai menurut Stephen Brookfield (2000:130-133) mengemukakan bahwa kemandirian belajar merupakan kesadaran diri, digerakkan oleh diri sendiri, kemampuan belajar untuk mencapai tujuannya.

Hasil analisa indikator kedua: Memiliki kepercayaan diri. Berdasarkan table.2 menggunakan bahan ajar matakuliah pembelajaran saintifik berdasarkan pembelajaran matematika memperoleh persentase sebesar $76,7 \%$. Sehingga dapat disimpulkan bahwa menggunakan bahan ajar matakuliah pembelajaran saintifik berdasarkan pembelajaran matematika dapat meningkatkan kepercayaan diri mahasiswa yang berada pada kategori sangat positif. Seseorang yang yakin terhadap dirinya, segala kegiatan yang dilakukannya penuh dengan rasa optimis adalah seseorang yang memiliki percaya diri. Rasa percaya diri yang tinggi sebenarnya hanya merujuk pada adanya beberapa aspek dari kehidupan individu tersebut dimana ia merasa memiliki kompetensi, yakin, mampu, dan percaya bahwa bisa karena didukung oleh pengalaman, potensi aktual, prestasi serta harapan yang realistik terhadap diri sendiri. Menurut Thursan Hakim (2002 : 6) "Rasa percaya diri juga dapat diartikan sebagai suatu keyakinan seseorang terhadap segala aspek kelebihan yang dimilikinya dan keyakinan tersebut membuatnya merasa mampu untuk 
bisa mencapai berbagai tujuan di dalam hidupnya".

Indikator ketiga yaitu berprilaku disiplin, berdasarkan hasil analisa memperoleh persentase sebesar 83,3 \% dan berkategori sangat positif. Disiplin merupakan sesuatu yang berkenaan dengan pengendalian diri atau kepatuhan seseorang untuk mengikuti bentukbentuk aturan atas kesadaran pribadinya, disiplin dalam belajar merupakan kemauan untuk belajar yang didorong oleh diri mahasiswa sendiri.

Indikator keempat dalam penelitia ini adalah memiliki rasa tanggung jawab memperoleh persentase sebesar 73,3 \%. Dengan demikian dapat disimpulkan bahwa rasa tanggung jawab mahasiswa berkategori positif.

Indikator kelima adalah Berperilaku berdasarkan inisiatif sendiri memperoleh persentase sebesar $76,7 \%$ dan berada pada kategori sangat positif. Menurut Utami Munandar (1990:48) mengungkapkan bahwa “ Inisiatif adalah kemampuan berdasarkan data atau informasi yang tersedia, menemukan banyak kemungkinan jawaban dari suatu masalah, dimana penekananya adalah pada kuantitas, ketepatgunaan, dan keragaman jawaban".

Indikator keenam yaitu Melakukan kontrol diri sebesar 70\%. Ini dapat disimpulkan bahwa mahasiswa dapat melakukan kontrol diri berada pada kategori positif. kemandirian belajar dapat terwujud jika pebelajar dapat mengontrol dirinya sendiri atas segala sesuatu yang dikerjakannya, mengevaluasi dan juga merencanakan sesuatu dalam proses belajarnya. Menurut Anggraeni (2014) pebelajar yang memiliki kontrol diri positif mampu mengelola informasi, mampu mengontrol emosi, dan mampu mengontrol perilaku emosional.

\section{KESIMPULAN}

Dari hasil penelitian diperoleh total keseluruhan jawaban responden mengenai kemandirian belajar mahasiswa saat penggunaan bahan ajar matakuliah pembelajaran saintifik berdasarkan pembelajaran matematika adalah sebesar 76,7
$\%$ yang merupakan kategori sangat positif. Hal tersebut dapat dilihat dari rincian setiap indikator sebagai berikut: (1) Ketidaktergantungan terhadap orang lain sebesar $80 \%$ yaitu berada pada kategori sangat positif. Hal ini menunjukkan bahwa mahasiswa belajar dengan menggunakan bahan ajar matakuliah pembelajaran saintifik berdasarkan pembelajaran matematika tidak bergantung pada orang lain. Mereka berusaha untuk belajar secara mandiri untuk memperoleh tujuan yang ingin dicapai. (2) Memiliki kepercayaan diri: penggunaan bahan ajar matakuliah pembelajaran saintifik berdasarkan pembelajaran matematika memperoleh persentase sebesar 76,7 \%. Sehingga dapat disimpulkan bahwa menggunakan bahan ajar matakuliah pembelajaran saintifik berdasarkan pembelajaran matematika dapat meningkatkan kepercayaan diri mahasiswa yang berada pada kategori sangat positif. (3) Disiplin: berdasarkan hasil analisa memperoleh persentase sebesar 83,3\% dan berkategori sangat positif. Disiplin merupakan sesuatu yang berkenaan dengan pengendalian diri atau kepatuhan seseorang untuk mengikuti bentukbentuk aturan atas kesadaran pribadinya, disiplin dalam belajar merupakan kemauan untuk belajar yang didorong oleh diri mahasiswa sendiri. (4) Memiliki rasa tanggung jawab memperoleh persentase sebesar 73,3\%. Dengan demikian dapat disimpulkan bahwa rasa tanggung jawab mahasiswa berkategori positif. (5) Berperilaku berdasarkan inisiatif sendiri memperoleh persentase sebesar 76,7 \% dan berada pada kategori sangat positif. (6) Melakukan kontrol diri sebesar 70\%. Ini dapat disimpulkan bahwa mahasiswa dapat melakukan kontrol diri berada pada kategori positif. kemandirian belajar dapat terwujud jika pebelajar dapat mengontrol dirinya sendiri atas segala sesuatu yang dikerjakannya, mengevaluasi dan juga merencanakan sesuatu dalam proses belajarnya.

\section{DAFTAR RUJUKAN}

Anggreini, R., \& Mariyanti, S. (2014). Hubungan antara kontrol diri dan perilaku konsumtif mahasiswi 
Universitas Esa Unggul. Jurnal

Psikologi Esa Unggul,12(01), 126664.

Brookfield,Stephen.2000.Understanding and Facilitating Adult Learning. Josey Bass Publisher. San Fransisco

Dick, W., Carey, L., dan Carey, J.O. 2009. The Systematic Design of Instruction. Pearson. New Jersey.

Hakim, Thursan. 2002. Mengatasi Rasa Tidak Percaya Diri. Jakarta: Puspa Swara.

Hidayati, K., \& Listyani, E. (2010). Improving Instruments of Students SelfRegulated Learning. J. Pendidik. Mat. Univ. Negeri Yogyakarta.

Kemendikbud.2013.Pendekatan Scientifik (ilmiah) dalam pembelajaran. Jakarta: Pusbangprodi

Mulyasa. 2006. Kurikulum Tingkat Satuan Pendidikan. Bandung: Rosdakarya

Munandar, S.C. Utami. 1990. Kreativitas dan Keberbakatan Strategi Mewujudkan Potensi Kreatif dan Bakat. Jakarta: Gramedia Pustaka Utama.

Sugiyono, (2011). Metode Penelitian Kuantitatif Kualitatif dan $R \& D$. Bandung: Alfabeta.

Susilowati, Desi. (2009). Upaya Meningkatkan Kemandirian Belajar dan Kemampuan Matematika Siswa Kelas X SMA N 1 Gamping dengan Menggunakan Lembar Kerja Siswa. Yogyakarta.UNY 